\title{
ステップ関数成分除去による強震加速度記録に基づく変位波形推定 ESTIMATION OF SEISMIC DISPLACEMENT FROM STRONG MOTION ACCELERATION RECORD BY ELIMINATING STEP FUNCTION COMPONENT
}

\author{
森脇 美 沙*1, 平井 敬*2, 福和伸夫*3 \\ Misa MORIWAKI, Takashi HIRAI and Nobuo FUKUWA
}

\begin{abstract}
A new calculation technique is proposed to estimate the seismic displacement from strong motion acceleration record. In the method, the displacement is obtained by eliminating the step function component from acceleration record in frequency domain. The parameters of step function component are determined to reduce the fluctuation of the displacement of coda part. Applying the method to the acceleration record of the main shock of the 2016 Kumamoto Earthquake, the displacement is obtained more accurately than that estimated by existing method. Furthermore, the method can also be applied to the record whose displacement cannot be computed by existing method.
\end{abstract}

Keywords : Residual displacement, Near-fault seismic ground motion, Fourier transform, Rectangular function, Kumamoto Earthquake 残留変位, 断層近傍地震動, フーリエ変換, 矩形関数, 熊本地震

1. はじめに

\section{1 研究の背景}

地震時の地動変位を知ることは, 建物や土木構造物の地震被害を 把握するのに有用であるなど, 大変重要である. 特に, 震源断層近 傍で発生する大きな残留変位を伴う地震動は, 免震建物や超高層建 物などの長周期構造物に大きな变位応答をもたらす可能性が指摘さ れている. 近年の強震観測点の高密度化により, 内陸の活断層地震 でこうした地震動がしばしば観測されるようになった。

地震による地動変位を知る方法として, GNSS による地殸変動観 測データの利用や, 強震観測記録に基づく残留変位の推定が挙げら れる. GNSS 観測データの信頼性はかなり高いが, 高精度の計測結 果を得るには 2 週間程度かかる。一方, 強震観測記録を利用すれば 記録終了時点で地動変位を算出することが可能である.さらに, 現 在の日本国内における強震観測点設置数は, 防災科学技術研究所に よる強震観測点のほか, 気象庁や地方公共団体が設置した震度計を 合わせただけでも 5000 点以上にのぼり, GNSS の電子基準点設置 数の約 1300 点と比較して圧倒的に多い, そのため, 強震観測記録 から推定される残留変位は GNSS 観測網を補完するものとしても 利用可能であると期待される.

強震観測記録の多くは加速度記録として得られる. 現在普及して いるサーボ型加速度計は, 長周期成分に対するゲインの落ち込みが 小さく, 原理的には強震加速度記録を二階時間積分することで残留
変位も含めた変位波形を求めることが可能である.しかし，実際に は強震加速度記録に基線変化が混入寸る場合が多く, 変位波形を精 度よく得るには土夫が必要になる.

強震加速度記録の基線変化の要因には諸説あるが, その一つとし て強震計の傾動が考えられている。例えば, Graizer (2005)は, 強震 記録には並進運動のほかに機器の傾動による回転成分が含まれてお り，断層近傍における残留変位を含むような強震加速度記録から変 位波形を得る際にはその影響が無視できないことを示した ${ }^{1)}$ 。また， 功刀・ほか(2018)は，直交 3 成分に斜交 1 成分を加えた 4 成分加速 度計で強震観測記録の分析を行い, 加速度基線変化の原因は電気的 な履歴現象ではなく加速度計筐体の傾動であると結論付けた ${ }^{2)}$. 一 方で，必ずしもそれのみでは説明がつかず，強い振動を受けるとセ ンサのゼロ点が振動以前の位置に戻らないという加速度センサの特 性例えば3)や，電気的なノイズによって加速度基線変化が生じる例えば4) という指摘もなされている.

\section{2 加速度基線変化の補正に関する先行研究}

実際の強震加速度記録から変位波形を得るには何らかの方法を用 いて基線変化の影響を除去する必要がある. 基線変化の影響は加速 度フーリエスペクトルの長周期領域に現れるため，一般的にはロー カットフィルタを用いてそれを除去し積分するという処理が広く行 われている.しかし，断層近傍の強震加速度記録に対してこれを行
*1 元 名古屋大学大学院環境学研究科 大学院生

*2 名古屋大学大学院環境学研究科 助教・博士 (工学)

*3 名古屋大学減災連携研究センター 教授. 工博
Former Grad. Student, Grad. School of Environmental Studies, Nagoya Univ. Assist. Prof., Grad. School of Environmental Studies, Nagoya Univ., Dr.Eng.

Prof., Disaster Mitigation Research Center, Nagoya Univ., Dr.Eng. 
うと残留変位を表現するために必要な長周期成分まで失われ, 変位 波形の歪みが生じて残留変位量を過小評価寸るおそれがある。 その ため，これまでに様々な変位波形を算出する工夫が提案されてきた． 時間領域で処理する方法として, Wu and Wu(2007)は, 加速度基 線補正後の変位波形はランプ関数になるとみなし变位波形の後続部 分が一定值になるよう調整する5)ことで補正した. Wang et al. (2011)は, 加速度基線補正後の変位波形はステップ関数になるとみ なし加速度波形の累積エネルギーと関連付けて調整する6)ことで補 正した. Moya et al. (2016)は, KiK-netのような鉛直アレイ観測地 点において, 地中と地表の残留変位量が等しくなるよう変位波形を 調整する 7)ことで加速度基線変化を補正した. ただし，この手法が 適用可能な記録は限定的であるという側面がある。 Graizer(1979) は加速度基線変化の影響を含む速度波形全体を 3 次関数で近似する 8)ことで補正した. Boore(2002)は加速度基線変化により現れる速度 波形のトレンドを 2 次関数で近似する 9 ことで補正し, 太田・アイ ダン (2007)はそれを折線関数で近似する 10)ことで補正した. 平井・ 福和(2012)は, Boore(2002) と太田・アイダン(2007)の方法を併用し た上で, 精度よくかつ多数の記録を自動処理できる方法を示した ${ }^{11)}$.

一方, 振動数領域において加速度記録から加速度基線変化を分離 し除去する方法として, Javelaud et al. (2011)や本山・室野(2012)は, 加速度波形に含まれる基線変化をステップ関数とみなし, それをフ ーリエスペクトルから図解的に検出・除去する方法を提案した ${ }^{4)}$, 12). しかし, 記録によってはこの方法により精度よく基線変化を検出す ることができないものもある.

そこで本研究では, 変位波形の後続部分の変動が最も小さくなる という条件の下, 振動数領域においてステップ関数状の加速度基線 変化を検出・除去するという新たな手法を提案する. 提案手法を 2016 年熊本地震本震の強震観測記録に対して適用したところ, 周 波数領域で基線変化補正を行う既存の手法より精度よく基線変化を 検出・補正し, 変位波形を推定することができた. さらに, 既存の手 法では基線変化の補正が不可能な記録でも, 本手法の適用により補 正が可能となった.

\section{2. 提案手法}

\section{1 振動数領域における加速度基線変化の補正}

加速度基線変化は地震動記録中のある時刻に一度だけ起こると仮 定すると, ステップ関数として表すことができる. Katukura and Hayashi(1991)による時間因果性を考慮した高速フーリエ変換 13)を 行うために後続の 0 を付加すると, 加速度記録の継続時間 $t_{\mathrm{d}}$ で基線 が 0 に戻るため, 加速度基線は次式のような矩形関数となる.

$$
s(t)=\alpha\left\{U\left(t-t_{\mathrm{r}}\right)-U\left(t-t_{\mathrm{d}}\right)\right\}
$$

ここで, $U(t)$ は単位ステップ関数, $\alpha$ は基線変化量, $t_{\mathrm{r}}$ は加速度基 線変化の発生時刻である. 加速度記録 $a^{\prime}(t)$ は, 微小なノイズを無視 寸ると, 真の地動加速度 $a(t)$ と矩形関数 $s(t)$ の和として次式で表せ る.

$$
a^{\prime}(t)=a(t)+s(t)
$$

式(2)をフーリエ変換すると,

$$
\begin{aligned}
A^{\prime}(\omega) & =A(\omega)+S(\omega) \\
& =\left\{\begin{array}{cc}
A(\omega)+\frac{2 \alpha \sin \omega\left(\frac{t_{\mathrm{d}}-t_{\mathrm{r}}}{2}\right)}{\omega} e^{-i \omega\left(\frac{t_{\mathrm{d}}+t_{\mathrm{r}}}{2}\right)} & (\omega \neq 0) \\
A(0)+\alpha\left(t_{\mathrm{d}}-t_{\mathrm{r}}\right) & (\omega=0)
\end{array}\right.
\end{aligned}
$$

ここで， $\omega$ は角振動数である. 式(3)の第 1 項は真の加速度フーリエ スペクトルで，一般に低振動数で 0 に近い值になる.一方, 第 2 項 は矩形関数のフーリエスペクトルであり, その值は振動数 0 のとき $\alpha\left(t_{\mathrm{d}}-t_{\mathrm{r}}\right)$, 振動数 $1 /\left(t_{\mathrm{d}}-t_{\mathrm{r}}\right)$ のとき 0 となる. さらに, 真の加速度フ ーリエスペクトル $A(\omega)$ について, 振動数 0 での值を 0 と仮定すれ ば， $\alpha$ は次のように表せる.

$$
\alpha=\frac{S(0)}{t_{\mathrm{d}}-t_{\mathrm{r}}}=\frac{A^{\prime}(0)-A(0)}{t_{\mathrm{d}}-t_{\mathrm{r}}}=\frac{A^{\prime}(0)}{t_{\mathrm{d}}-t_{\mathrm{r}}}
$$

すなわち, 矩形関数のパラメータ $t_{\mathrm{r}}$ の值を仮定すれば自動的にパラ メータ $\alpha$ の值も定まる. パラメータ $t_{\mathrm{r}}$ の最適值の推定方法は, 次の 2.2 節で述べる. パラメータ $t_{\mathrm{r}}, \alpha$ により決定された矩形関数のフ ーリエスペクトル $S(\omega)$ を加速度記録のフーリエスペクトル $A^{\prime}(\omega)$ から除くことで, 加速度基線変化が補正された加速度フーリエスペ クトル $A(\omega)$ が求められる.

$$
A(\omega)=A^{\prime}(\omega)-S(\omega)
$$

この補正された加速度フーリエスペクトル $A(\omega)$ をフーリエ逆変 換すると補正された加速度波形が得られ，さらにこれを二階時間積 分寸ると補正された変位波形が得られる. 本山・室野(2012)は, 式 (3)のスペクトルの絶対值のグラフで, 最初に值が落ち込む振動数 を読み取ることにより基線変化の開始時刻 $t_{\mathrm{r}}$ を求めている ${ }^{12)}$. しか し，記録によってはスペクトルの值の落ち込みが明瞭ではなく, $t_{\mathrm{r}}$ の推定を誤る場合や, 判読不能の場合がある. 本研究は, そのよう な場合でも矩形関数のパラメータ $t_{\mathrm{r}}$ および $\alpha$ の推定が可能となる新 たな手法を提案するものである.

\section{2 矩形関数のパラメータ推定方法}

地震によって強震観測地点に液状化等の地盤変状が生じていなけ れば, 適切に加速度基線変化を補正することで主要動終了後の変位 はある一定值に収束すると考えられる，よって, 評価関数 $P$ を次式 のように定義し, これが最小となるパラメータ $t_{\mathrm{r}}, \alpha$ を探索する.

$$
P=\frac{1}{\left|D_{\mathrm{m}}\right|} \sqrt{\frac{1}{t_{\mathrm{d}}-t_{\mathrm{m}}} \int_{t_{\mathrm{m}}}^{t_{\mathrm{d}}}\left\{d(t)-D_{\mathrm{m}}\right\}^{2} d t}
$$

ここで， $t_{\mathrm{m}}$ は主要動終了時刻であり, 秋山・北村(2006)14)を参考に, 加速度波形の二乗累積值が全体の $95 \%$ に達する時刻と定義した。 $d(t)$ は評価関数值を算出する対象の変位波形であり, パラメータ $t_{\mathrm{r}}$ の仮定值による加速度基線変化補正を施して求められたものとする. また, $D_{\mathrm{m}}$ は主要動終了後の平均変位で, 次のように定められる.

$$
D_{\mathrm{m}}=\frac{1}{t_{\mathrm{d}}-t_{\mathrm{m}}} \int_{t_{\mathrm{m}}}^{t_{\mathrm{d}}} d(t) d t
$$

式(6)で表される評価関数 $P$ は, 主要動終了後の変位の標準偏差 を平均変位 $D_{\mathrm{m}}$ の絶対值で除したものであり, この值が小さいほど 変位波形がある一定の值によく収束していることを表している.ま た, 本論文の 3 章以降では評価関数 $P$ の值を変位波形の「変動率」, 主要動終了後の平均変位 $D_{\mathrm{m}}$ の值を「残留変位」と呼ぶ. 


\section{3 提案手法による波形処理の流れ}

本論文で提案する加速度基線変化補正方法の核心部は 2.2 節で述 べたが，実際に加速度記録から変位波形を算出する過程には，次の ようにいくつかの段階がある.

（1）加速度記録の初動以前の区間の平均加速度の值を，加速度記 録全体から差し引く.

（2）加速度記録の一階時間積分により速度波形を，二階時間積分 により変位波形を算出する。

（3）速度波形に直線状のトレンドが認められる，または変位波形 が放物線状に発散している場合は $2.1 \sim 2.2$ 節で示した加速度 基線変化補正を施す，その詳細な手順は以下の通りである.

(1) 時間因果性を考慮して地震動加速度記録のフーリエ変換を行 う.

(2) パラメータ $t_{\mathrm{r}}$ の值を仮定し，それに対応したパラメータ $\alpha$ の值を式(4)から求める.

(3) (2)で定めたパラメータ $t_{\mathrm{r}}, \alpha$ を用いて矩形関数のフーリエスペ クトル $S(\omega)$ を算出し, 式(5)を用いて補正された加速度フーリ エスペクトル $A(\omega)$ を求める.

(4) 補正された加速度フーリエスペクトル $A(\omega)$ に基づき時刻歴変 位波形を算出する.

(5) (4)で求めた変位波形を用いて, 式(6)および式(7)から評価関数 $P$ の值を求める.

(6) パラメータ $t_{\mathrm{r}}$ の值を変化させて(2)～(5)の手順を繰り返し，評 価関数 $P$ の值が最小となるときのパラメータ $t_{\mathrm{r}}$ の值を探索す る.

(7) 最適化されたパラメータ $t_{\mathrm{r}}, \alpha$ による矩形関数成分を除去し て得られた変位波形が, 加速度基線変化補正後の変位波形と して最終的に決定される.

手順(3) (4)で, 補正された加速度フーリエスペクトル $A(\omega)$ から時 刻歴変位波形を求めるための積分方法は種々存在する. 本研究では, 補正された加速度フーリエスペクトル $A(\omega)$ に対してフーリエ逆変 換を行って補正加速度波形を算出した後, 線形加速度法を用いて時 刻歴変位波形を算出している. なお, 本山・室野(2012)は矩形関数を 除去した後必要に応じてローカットフィルタを併用した上で, 林・ ほか(1991)が提案したフーリエスペクトルの実部を用いた振動数領 域における積分 ${ }^{15)}$ を利用して変位波形を算出している. 本論文にお いてはローカットフィルタを使用しないため, 時間領域での積分と 林・ほか(1991)の積分方法は等価である。

\section{3. 提案手法の適用}

\section{1 適用例}

提案手法の適用例として, 2016 年 4 月 16 日 1 時 25 分に発生し た熊本地震本震において, 震源断層である布田川断層近傍に位置す る西原村小森(93038)で観測された地表地震動記録の東西成分を取 り上げる.

まず，収録開始から $60 \mathrm{~s}$ までの記録を抽出した，その際，加速度 基線変化が生じていることを確認するのに十分なデータ長を確保し つつ, 抽出記録の中で加速度基線変化が 2 回以上発生していること がないよう留意した. 次に, 初動以前の $0 \sim 10 \mathrm{~s}$ 区間の加速度平均 值を加速度記録全体から差し引いた，その上で時間積分によって速
度波形および変位波形を算出したところ, 加速度基線変化が生じて いることが認められたため, 2 章で示した方法により加速度基線変 化補正を行った。

図 1 に, 提案手法による加速度基線変化補正前後の(a)加速度, (b) 速度, (c)変位波形を示す. 加速度波形では補正前後の違いがほとん どわからないが，速度波形では基線変化補正を行ったことにより直 線状のトレンドが除去されたことが見て取れる。その結果，変位波 形では負方向への放物線状の発散が生じなくなり，真の変位波形に 近い波形が得られたことがわかる. (c)には，本山・室野(2012)の方法 およびローカットフィルタ(遮断振動数 $0.03 \mathrm{~Hz}$ )の適用により算出 した変位波形も併せて示した。提案手法により算出した変位波形は, 本山・室野(2012)の方法で算出した変位波形と比較すると, 波形の 後続部分の湾曲がより改善されていることが見て取れる。また，ロ 一カットフィルタを適用して算出した変位波形は歪みが生じており, 残留変位がほぼ存在しないという誤った推定結果となった。

図 2 に, 基線変化補正前の加速度, 推定された矩形関数, 補正後 の加速度について，それぞれフーリエスペクトルの絶対值を示す． 基線変化補正前の加速度波形フーリエスペクトルでは, 振動数約 $0.03 \mathrm{~Hz}$ 以下の領域で基線変化による矩形関数成分の影響が現れて いることがわかる。一方，補正された加速度フーリエスペクトルで は，基線変化の影響が除去されているのが見て取れる。ちなみに， 本山・室野(2012)の方法では, 補正前の加速度フーリエスペクトル の值が最初に落ち込む振動数を精度よく読み取るため, 高速フーリ 工変換を行う際に後続の 0 をデータ数が 100 万以上になるよう付加 しており ${ }^{12)}$ ，この付加量が矩形関数成分の検出精度に与える影響は 大きい，しかし提案手法では，後続の 0 は時間因果性を考慮して高 速フーリエ変換を行うための必要最低限（例えばデータ数が 6000 の記録の場合, データ数が $2^{14}=16384$ となるように）付加すればよ く,またそれ以上付加量を増加させても矩形関数成分の推定結果は 変化しない.したがって, 本手法は後続の 0 の付加量に左右されず 一定の矩形関数成分の検出精度を保持していると言える.

図 3 に, 基線変化時刻 $t_{\mathrm{r}}$ の值に対する変動率 $P$ の值のグラフを示 す. 基線変化量 $\alpha$ は，式(4)で示したように $t_{\mathrm{r}}$ の值を仮定すると定ま るため, その条件下における $\alpha$ の值を用いて変動率 $P$ を算出した. $t_{\mathrm{r}}$ の仮定值を一定の細かな時間刻み（本研究では $0.001 \mathrm{~s}$ 刻みとし た）で変化させてそれぞれ変動率 $P$ を求め, その值が最小となる $t_{\mathrm{r}}$ を探索した. その結果, 変動率の最小值は $P=0.0163$ であった. 各 パラメータの最適值は $t_{\mathrm{r}}=26.96 \mathrm{~s}, \alpha=-1.40 \mathrm{~cm} / \mathrm{s}^{2}$ と決定され, 残 留変位は $D_{\mathrm{m}}=161 \mathrm{~cm}$ であった. なお，本山・室野(2012)の方法で矩 形関数成分のパラメータを推定したところ $t_{\mathrm{r}}=25.05 \mathrm{~s} ， \alpha=-1.32$ $\mathrm{cm} / \mathrm{s}^{2}$ となった。 また，その矩形関数成分を除去して得られた変位 波形に対し, 式(6) と(7)を用いて変動率 $P$ と残留変位 $D_{\mathrm{m}}$ を算出した ところ，P=0.0463， $D_{\mathrm{m}}=196 \mathrm{~cm}$ となった。したがって，提案手 法により算出した変位波形は, 本山・室野(2012)の方法で算出した 変位波形と比較して変動率が小さく, 変位波形の収束の程度が向上 していることがわかる.

なお，国土交通省国土地理院による緊急 GNSS 観測の結果注 2) に よると, 西原村小森(93038)から北西一約 $265 \mathrm{~m}$ の距離にある 2 級 基準点（西）基 II -2 では，図 1(c)に示したように東方向に約 $141 \mathrm{~cm}$ の地動変位が記録されている. 2 級基準点（西）基 II - 2 は西原村小森 

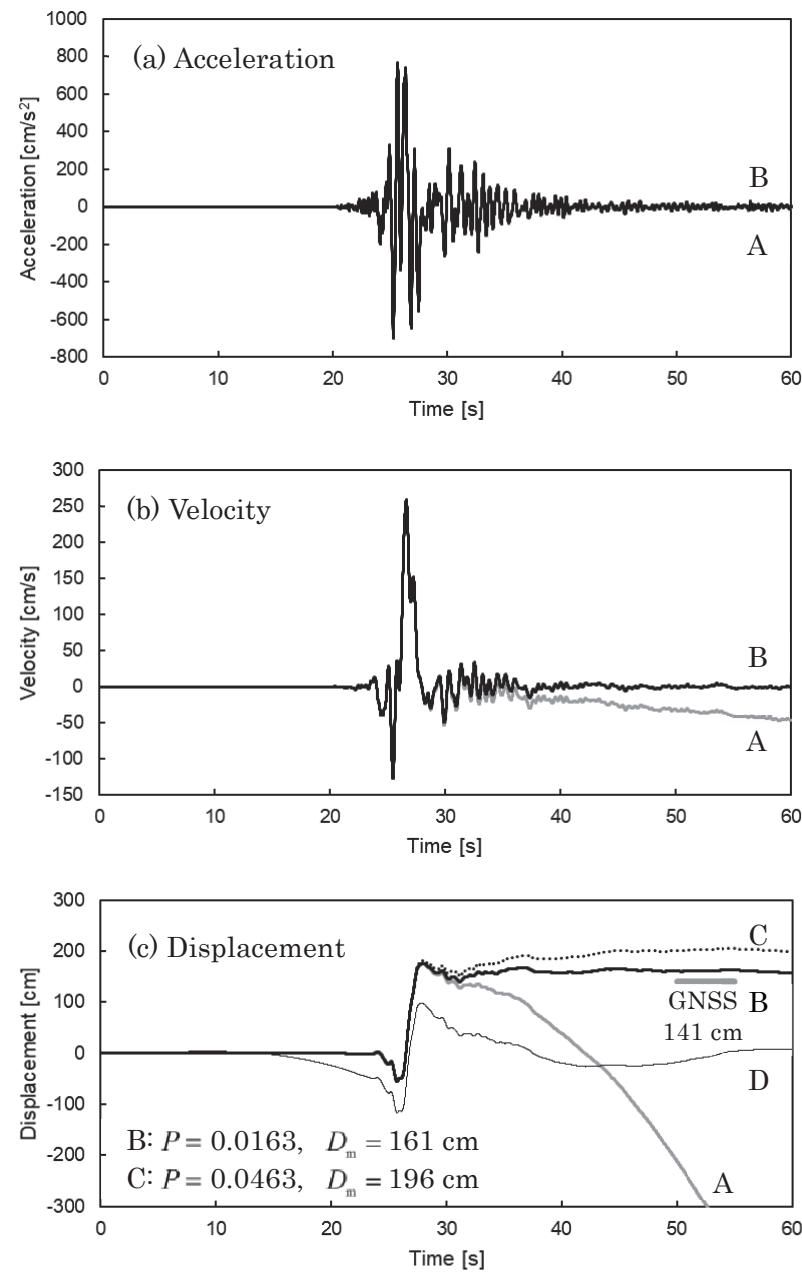

A: Uncorrected

B: Corrected by proposed method

C: Corrected by Motoyama and Murono(2012)

D: Corrected by low-cut filter $(0.03 \mathrm{~Hz})$

Fig.1 (a) Acceleration, (b) velocity, (c) displacement before and after baseline change correction for EW component at Nishihara(93038)

(93038) と比べて震源断層から少し遠ざかった地点にあることを考 慮すれば, 緊急 GNSS 観測の結果と提案手法により得られた西原村 小森(93038)の残留変位（東方向へ $161 \mathrm{~cm}$ ） は整合的である.

図 4 に, 西原村小森(93038)観測点における南北および上下成分 の加速度記録に対して, 同様に変位波形を算出した結果を示す. 提 案手法による補正前後の波形に加え, 本山・室野(2012)の方法によ り得られた変位波形も併せて示した. 南北成分は, 提案手法で算出 したほうが本山・室野(2012)の方法で算出するのに比べて変動率が 小さく, 変位波形の収束の程度が向上した。また，上下成分は本山・ 室野(2012)の方法では補正不可能であったが，提案手法の適用によ り補正が可能となった. さらに, 東西成分と同様に南北・上下成分 についても，提案手法により得られた残留変位量と 2 級基準点（西） 基II-2 における緊急 GNSS 観測の結果注 2)を比較したところ, 各成 分ともに両者は整合的であった。

図 5 に, 提案手法を適用して求めた変位波形を用いて, 水平面,

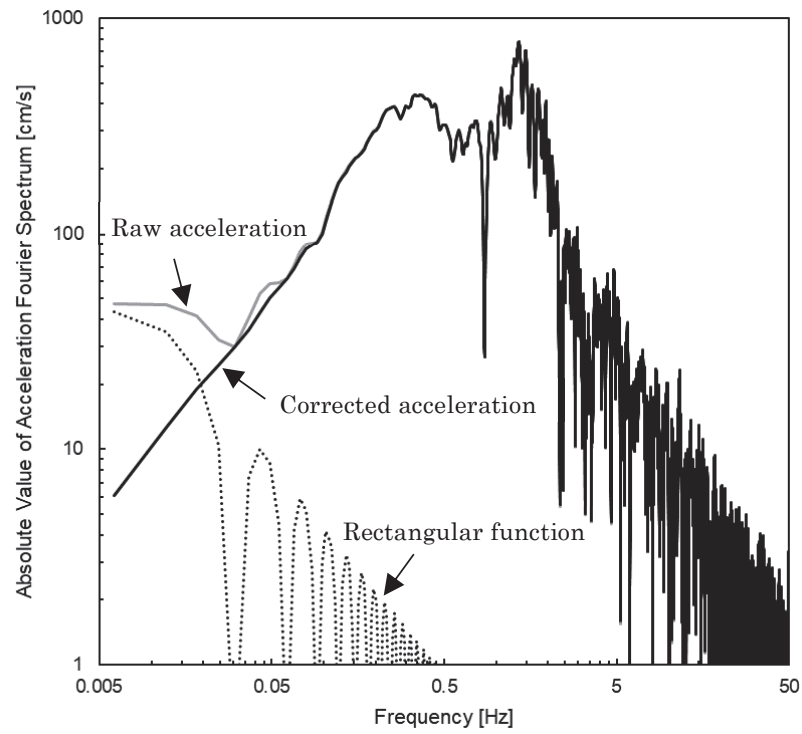

Fig.2 Fourier spectra of acceleration

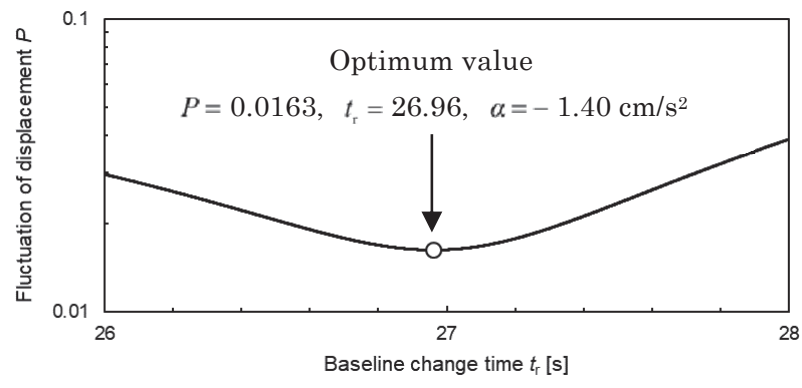

Fig.3 Estimation of baseline change time
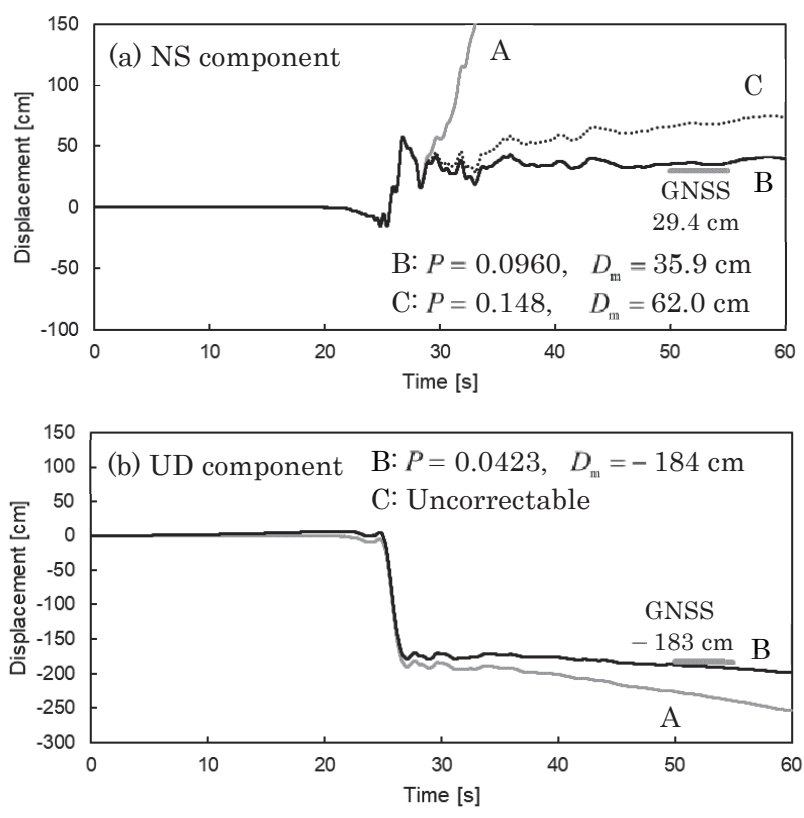

A: Uncorrected

B: Corrected by proposed method

C: Corrected by Motoyama and Murono(2012)

Fig.4 (a) NS and (b) UD component of the displacement at Nishihara(93038) 

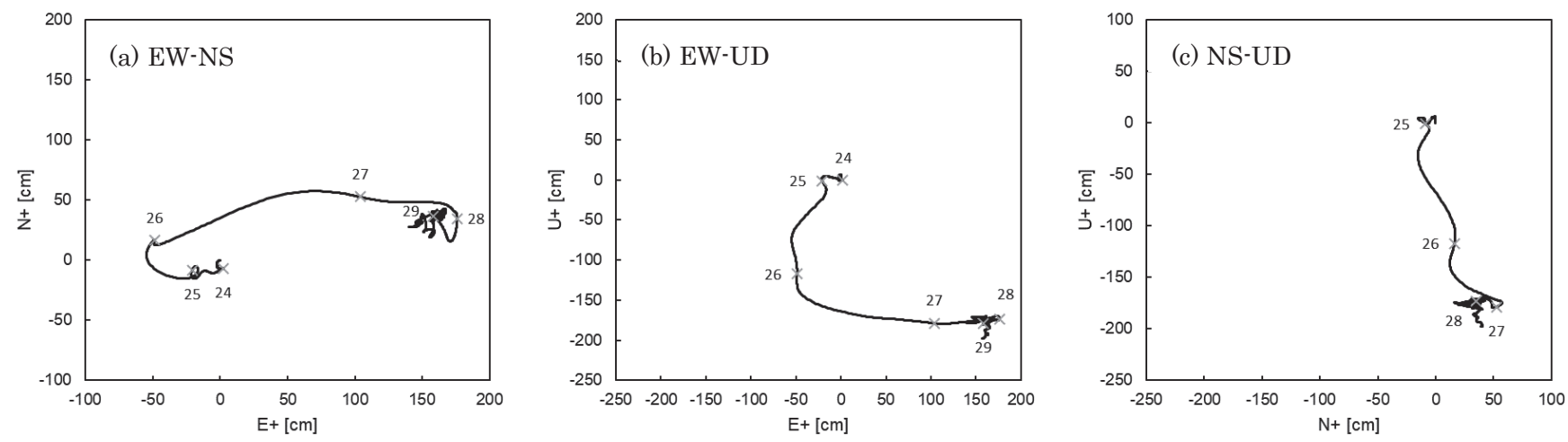

Fig. 5 The orbit of the particle motion of the ground motion at Nishihara(93038)

東西一上下面, 南北一上下面の粒子軌跡を描いた注1)ものを示す. 粒子軌跡上の $\times$ 印は 1 秒ごとの位置を示したもので, 数字は記録開 始からの経過秒数である. 西原村小森(93038)観測点の地盤の沈降・ 水平移動は同時に発生したのではなく, まず約 1 秒 $(25 \sim 26 \mathrm{~s})$ かけ て約 $150 \mathrm{~cm}$ 沈降し, その後約 2 秒 $(26 \sim 28 \mathrm{~s})$ かけて東一約 $200 \mathrm{~cm}$ 移動していたことがわかる.

\section{2 適用性の検討}

提案手法の適用性を検討するため, K-NET および KiK-net の観 測点についても, 熊本地震本震で得られた強震記録に対し提案手法 を用いて変位波形を算出した. 対象として, 震央距離約 $30 \mathrm{~km}$ の範 囲に存在し, 特に大きな変位が生じたと考えられる K-NET 大津 (KMM005), K-NET 熊本(KMM006), K-NET 砥用(KMM011), KiKnet 菊池(KMMH03), KiK-net 豊野(KMMH14), KiK-net 益城 (KMMH16)の記録を選定した. なお, KiK-netの観測点については, すべて地表の記録を使用した。

図 6 に, 各強震観測点の変位波形を算出した結果を示す. 提案手 法による基線変化補正前後の変位波形に加えて, 本山・室野(2012) の方法により算出した変位波形も併せて示している. 提案手法およ び本山・室野(2012)の方法による補正後の変位波形については, 残 留変位 $D_{\mathrm{m}}$ および変動率 $P$ をそれぞれ図中に記載している。いずれ の地点においても, 提案手法により算出された変位波形の方が変動 率 $P$ の值が小さく, 基線変化の検出精度が向上していることがわか る. 特に K-NET 大津 $(\mathrm{KMM} 005)$ の東西成分は, 低振動数領域でス ペクトルの值の落ち込みが明瞭に現れず, 本山・室野(2012)の手法 を適用することができない，しかし，提案手法を用いることで基線 変化補正が可能となり，変位波形の発散を抑制することができた。

しかしながら，例えば K-NET 熊本(KMM006)の南北成分や KiK-net 菊池(KMMH03)の東西成分, KiK-net 豊野(KMMH14)の東 西成分のように, 提案手法を用いて基線変化補正を施しても変位波 形の後続部分で湾曲が残る場合もあった. これは加速度波形上でス テップ関数状の特徵を示さないため提案手法により除去することが できない, 不規則な電気ノイズ等を原因とする長周期ノイズの影響 であると考えられる. 残留変位量が $10 \mathrm{~cm}$ 程度と小さい記録は, S/N 比が小さくなり長周期ノイズの影響が大きくなるため, 変位波形の 推定精度は低くなる。このような場合, 基線変化補正を施した後に 線形加速度法を用いるのではなく，長周期ノイズの影響を低減する
ことが可能な積分方法を適用し補正することが考えられる。例えば 平井(2018)は，変位波形に含まれる台形関数成分をスペクトルフィ ッティングにより検出し，ノイズが含まれる低振動数成分を台形関 数のそれで置換した上で林・ほか(1991)の方法による積分を行い, 長周期ノイズの影響を除去する方法を提案している ${ }^{16)}$.ただし, 図 6 に示した各観測点の変位波形を観察すると, 台形関数と三角形パ ルスを足し合わせたような形状が特徵的であるものが多い，台形関 数状の波形は「フリングステップ」，三角形パルス状の波形は「長 周期パルス」などと呼ばれており，これらは震源断層近傍で観測さ れる特徴的な地震動波形である。したがって, 変位波形を台形関数 で近似している平井(2018)の方法によって断層近傍地震動による変 位波形の補正を行うと, 最終的に得られる残留変位量の算出精度の 向上が期待できる一方で,変位波形としては三角形パルス的な特徵 が失われ真の地盤挙動から乘離してしまう可能性も考えられる.

提案手法により算出した変位波形から残留変位 $D_{\mathrm{m}}$ が得られるた め，それを用いて地震後の残留変位の分布を知ることができる. 図 7 に, 各観測点の変位波形から算出した, 水平方向の残留変位の向 きと大きさを示寸.なお, GNSS 連続観測網 GEONET の電子基準 点の 2016 年 4 月 15 日 12:00 から 2016 年 4 月 6 日 12:00 までの 1

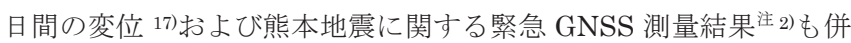
せて描画した。これらには熊本地震本震のみならず余震活動の影響 も含まれるが, 対象期間における最大の余震の気象庁マグニチュー ドは 5.9 , 震源深さは $11 \mathrm{~km}$ で, 地動変位に与える影響は小さいと 考えられる。なお, GNSS 連続観測網 GEONET により得られる地 動変位量は, 電子基準点「つくば $1 」 に$ 対する相対変位である. 強震 観測点と GNSS 観測地点は同一地点ではないため直接比較するこ とはできないが, 提案手法により算出された残留変位は GNSS の観 測結果と整合していることがわかる。ただし，K-NET 熊本 (KMM006)や KiK-net 菊池(KMMH03), KiK-net 豊野(KMMH14)な どの記録については, 先述の通り，長周期ノイズの影響により南北 成分の残留変位量が正しく算出できていない可能性があることに注 意する必要がある.

\section{4. 結論と今後の課題}

本研究では, 震源断層近傍における強震加速度記録に基づき残留 変位も含めた変位波形を精度よく算出する方法として, 主要動終了 後の変位変動率が小さくなるよう, 振動数領域において加速度基線 

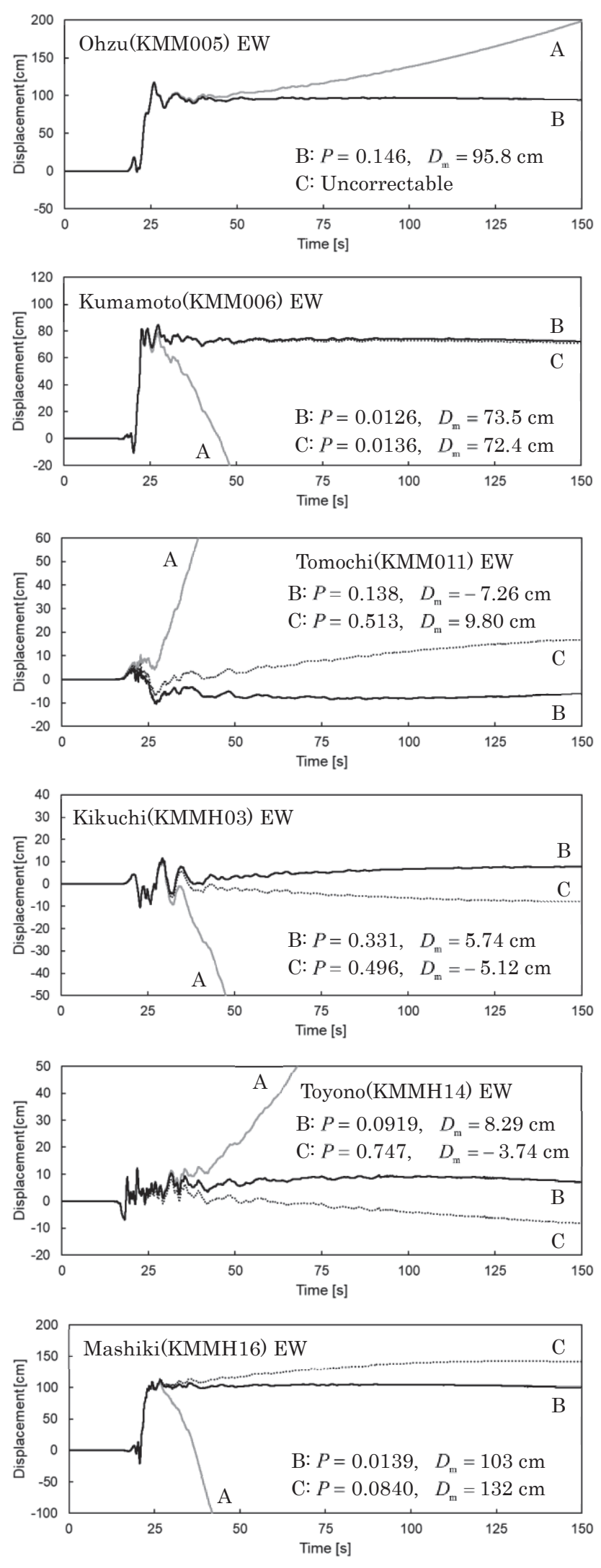

A: Uncorrected

C: Corrected by Motoyama and Murono(2012)
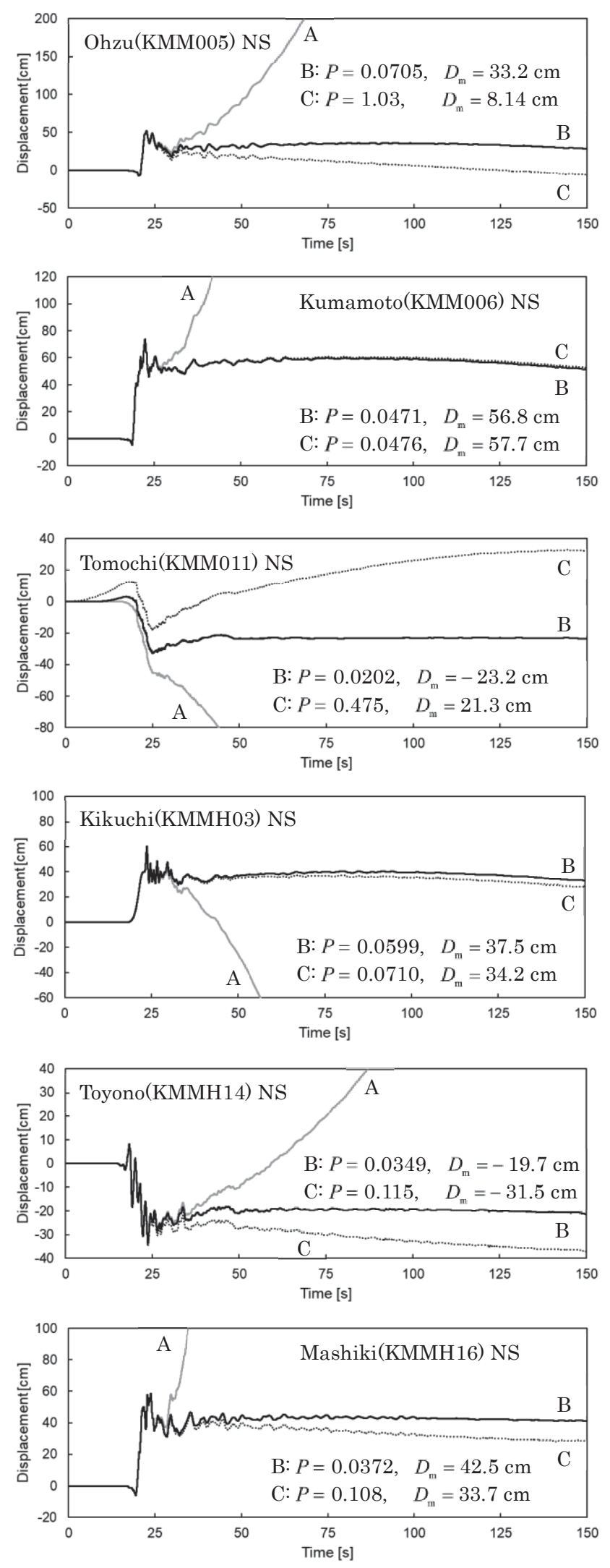

B: Corrected by proposed method

Fig. 6 Displacements of the main shock of the 2016 Kumamoto Earthquake 
変化によるステップ関数成分を検出・除去する手法を提案した. 2016 年熊本地震本震の西原村の記録に対して提案手法を適用して 算出した変位波形は, 本山・室野(2012)の方法により算出した場合 と比較して, 主要動終了後の変位波形の収束の程度が改善したのに 加えて, 本山・室野(2012)の方法では基線変化補正が不可能であっ た記録についても補正が可能となった。また，同じ地震による他の 地点の強震記録に対しても提案手法を適用したところ，同様の結果 が得られた. よって本手法は, 既存の振動数領域における加速度基 線変化補正手法よりも変位波形の算出精度を向上させ，かつ適用対 象の拡大を実現したものであると言える.

ただし, 提案手法は主要動終了後の変位の変動率が小さくなると いう条件の下で加速度基線変化の検出を行うことから, 残留変位が 小さい記録の場合はコーダ波の影響により変位が一定值に収束して も変動率が小さくなるとは限らないため, 提案手法が適用しにくく なる可能性がある. また, 提案手法では対象とする地震動加速度記 録で基線変化が発生する回数を 1 回に限定しており, 2 回以上の場 合については考慮していない. 主要動終了後の後続部分で 2 回目以 降の基線変化が発生している場合は，それ以前の区間を抽出するこ とで本手法を適用することが可能である.しかし, 主要動継続区間 中に大きな基線変化が 2 回以上発生していた場合, 本手法を適用し ても精度よく変位波形が得られないと考えられる. 複数のステップ 関数を設定しパラメータ探索することは可能であろうが, 加速度基 線の形状が複雑になるため検出は困難であると考えられる.したが って, 本手法の適用の可否は対象と寸る記録に対し個別に判断しな ければならない,さらに, 地震動加速度記録にステップ関数成分以 外のノイズが含まれる場合, 提案手法のみでは精度よく変位波形を 算出することができない，そのような波形については，ノイズを補 正することが可能な積分手法を併用することでその影響を低減でき る可能性がある.ただし断層近傍地震動を扱う場合, 台形関数と三 角形パルスを足し合わせたような特有の変位波形の形状を考慮する 必要がある.これらの諸問題については, 今後検討を進めていくこ ととしたい.

\section{謝辞}

本研究にあたり, 国立研究開発法人防災科学技術研究所の強震観 測網 K-NET, KiK-net の公開データおよび熊本県が設置した震度計 の強震記録を使用した。 また, 国土交通省国土地理院の GNSS 連続 観測網 GEONET の日々の座標值 (F3 解) を参照した. さらに, 国 土交通省国土地理院より, 熊本地震に関する緊急 GNSS 観測の結果 の数值データをご提供いただいた. 本論文の図の一部は, Generic Mapping Tools (GMT) 19)を用いて作成した. それぞれ，ここに感謝 の意を表する.

注

注 1）熊本地震本震の地震動記録から変位波形を算出し, 水平面内の粒子軌 跡を描いた報告として, 岩田知孝: 益城町宮園・西原村小森本震記録の 解析 (http://sms.dpri.kyoto-u.ac.jp/eq20160414.html, 2016.4.27 公表, 2016.4.28 更新, 2018.12.01 参照) が存在する. 本論文の図 6 (a)で求め た西原村小森の水平面内の粒子軌跡と, 上記の報告における西原村小 森の粒子軌跡はほぼ一致している.

注 2）国土交通省国土地理院より緊急 GNSS 観測の結果をご提供いただいた. このデータは熊本県内に設置されている電子基準点のうち, 熊本

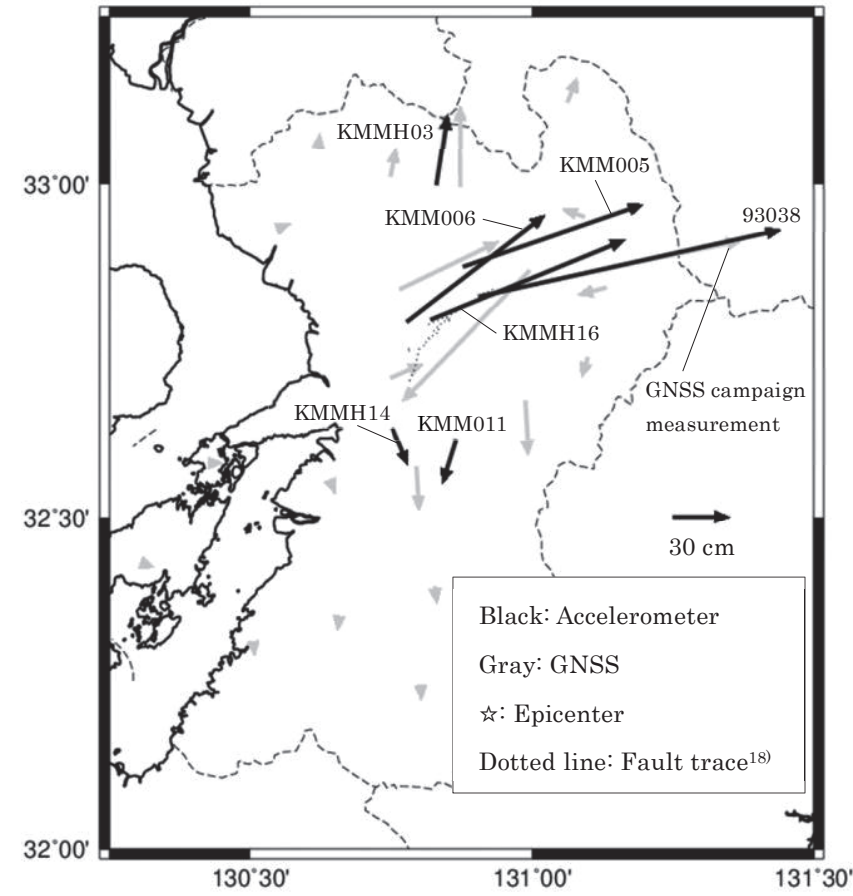

Fig. 7 Residual displacement distribution of the main shock of the 2016 Kumamoto Earthquake

（950465），城南（021071），矢部 A(081169），長陽(960701）を使用 した網平均より求めた座標と成果の比較により得られた変位量である. なお，上下変動量については国土交通省国土地理院「平成 28 年熊本地 震に関する情報」(https://www.gsi.go.jp/BOUSAI/H27-kumamotoearthquake-index.html）の「緊急 GNSS 観測の結果」にて公開されて いる.

\section{参考文献}

1) V. M. Graizer: Effect of tilt on strong motion data processing, Soil Dynamics and Earthquake Engineering, Vol.25, No.3, pp.197-204, 2005.4

2) T. Kunugi, W. Suzuki, H. Kubo, S. Aoi, H. Nakamura, and H. Fujiwara: Validation check of strong-motion records using four component accelerometer, Programme and Abstracts, The Seismological Society of Japan 2018, Fall Meeting, pp.300, 2018.10 (in Japanese) 功刀卓, 鈴木亘, 久保久彦, 青井真, 中村洋光, 藤原広行：4 成分加速度計 を用いた強震記録の信頼性検証, 日本地震学会講演予稿集, 2018 年度秋 季大会, pp.300, 2018.10

3) W. Iwan, M. Moster, and C. Peng: Some Observations on strong-motion earthquake measurement using a digital accelerograph, Bulletin of the Seismological Society of America, Vol.75, No.5, pp.1225-1246, 1985.10

4) E. Javelaud, T. Ohmachi, and S. Inoue: A quamtitative approach for estimating coseismic displacements in the near field from strongmotion accelerographs, Bulletin of the Seismological Society of America, Vol.101, No.3, pp.1182-1198, 2011.7

5) Y. Wu and C. Wu: Approximate recovery of coseismic deformation from Taiwan strong-motion records, Journal of Seismology, Vol.11, pp.159$170,2007.4$

6) R. Wang, B. Schurr, C. Milkereit, Z. Shao, and M. Jin: An improved automatic scheme for empirical baseline correction of digital strongmotion records, Bulletin of the Seismological Society of America, Vol.101, No.5, pp.2029-2044, 2011.10

7) L. Moya, W. Liu, and F. Yamazaki: Comparison of coseismic displacements obtained from geonet and seismic networks, Journal of Earthquake and Tsunami, Vol.10, 1640002, 2016.6

8) V. M. Graizer: Determination of the ground displacement by using 
9) David M. Boore, Christopher D. Stephens, and William B. Joyner: Comments on Baseline Correction of Digital Strong-Motion Data: Examples from the 1999 Hector Mine, California, Earthquake, Bulletin of the Seismological Society of America, Vol. 92, No. 4, pp. 1543-1560, 2002.5

10) Y. Ohta and Ö. Aydan: An integration technique for ground displacement from acceleration records and its application to actual earthquake records, Journal of The School of Marine Science and Technology, Tokai University, Vol.5, No.2, pp.1-12, 2007.11 (in Japanese)

太田良巳，アイダン・オメル：加速度から変位を求める積分手法と実地震 記録への適用, 「海一自然と文化」東海大学紀要海洋学部, Vol.5, No.2, pp.1-12, 2007.11

11) T. Hirai and N. Fukuwa: Estimation of crustal deformation distribution due to the 2011 Of the Pacific coast of Tohoku Earthquake based on strong motion records, Journal of Structural and Construction Engineering (Transactions of AIJ), Vol.77, No.673, pp.341-350, 2012.5 (in Japanese)

平井敬，福和伸夫：強震記録に基づく東北地方太平洋沖地震による地款 変動分布の算定, 日本建築学会構造系論文集, Vol.77, No.673, pp.341-350, 2012.5

12) H. Motoyama and Y. Murono: Calculation technique for acquire displacement from seismic acceleration records, Journal of the Japan Society of Civil Engineers, A1, Vol/68, No.4, pp.I_202-I_208, 2012.7 (in Japanese)

本山紘希・室野剛隆：地震加速度記録の積分による変位波形の計算手法, 土木学会論文集 A1(構造 ·地震工学), Vol.68, No.4, pp.I_202-I_208, 2012.7

13) H. Katukura and Y. Hayashi: Causal FFT treatment applicable to singularity functions, International Journal for Methods in Engineering, Vol.31, pp.53-66, 1991

14) H. Akiyama and H. Kitamura: Relationship between energy spectra and velocity response spectra, Journal of Structural and Construction Engineering (Transactions of AIJ), No.608, pp.37-43, 2006.10 (in Japanese)

秋山宏・北村春幸：エネルギースペクトルと速度応答スペクトルの対応， 日本建築学会構造系論文集, No.608, pp.37-43, 2006.10

15) Y. Hayashi, H. Katsukura, T. Watanabe, S. Kataoka, H. Yokota, and T. Tanaka: Reliability of integrated displacements from accelerograms by digital accelerographs, Journal of Structural and Construction Engineering (Transactions of AIJ), No.419, pp.57-66, 1991.1 (in Japanese)

林康裕, 勝倉裕, 渡辺孝英, 片岡俊一, 横田治彦, 田中貞二: デジタル強 震計の加速度記録を積分して得られる変位の信頼性について, 日本建築 学会構造系論文集, No.419, pp.57-66, 1991.1

16) T. Hirai: Estimation of ground displacement from seismic acceleration record by spectral fitting to trapezoidal function, Journal of Structural and Construction Engineering (Transactions of AIJ), Vol.83, No.751, pp.1229-1238, 2018.9 (in Japanese)

平井敬：台形関数へのスペクトルフィッティングによる地震動加速度記 録に基づく変位波形の推定, 日本建築学会構造系論文集, Vol.83, No.751, pp.1229-1238, 2018.9

17) Geospatial Information Authority of Japan: GNSS Earth Observation Network System, http://terras.gsi.go.jp/ (2018.10.15 referred) 国土地理院：電子基準点データ提供サービス, http://terras.gsi.go.jp/ (2018.10.15 参照)

18) Y. Shirahama, M. Yoshimi, Y. Awata, T. Maruyama, T. Azuma, Y. Miyashita, H. Mori, K. Imanishi, N. Takeda, T. Ochi, M. Otsubo, D. Asahina and A. Miyakawa: Characteristics of the surface ruptures associated with the 2016 Kumamoto earthquake sequence, central Kyushu, Japan, Earth, Planets and Space, 68:191, 2016.11

19) P. Wessel, W. H. F. Smith, R. Scharroo, J. F. Luis, and F. Wobbe: Generic Mapping Tools: Improved version released, EOS Transactions of American Geophysical Union, Vol.94, No.45, pp.409-410, 2013.11 


\title{
ESTIMATION OF SEISMIC DISPLACEMENT FROM STRONG MOTION ACCELERATION RECORD BY ELIMINATING STEP FUNCTION COMPONENT
}

\author{
Misa MORIWAKI ${ }^{* 1}$, Takashi HIRAI ${ }^{* 2}$ and Nobuo FUKUWA*3 \\ ${ }^{* 1}$ Former Grad. Student, Grad. School of Environmental Studies, Nagoya Univ. \\ *2 Assist. Prof., Grad. School of Environmental Studies, Nagoya Univ., Dr.Eng. \\ ${ }^{*}$ Prof., Disaster Mitigation Research Center, Nagoya Univ., Dr.Eng.
}

A seismic displacement brings us the useful information to analyze the seismic damage of infrastructure and buildings. In particular, a near-fault seismic ground motion including the huge residual displacement may cause the large response of tall buildings and base isolated buildings.

The residual displacement due to the earthquake is obtained from geodetic observations such as GNSS, while the time series of the displacement including the residual component can be estimated using the strong ground motion record. Generally, residual displacements obtained by geodetic observations are more accurate. However, residual displacements estimated from strong ground motion records can be used to investigate the distribution of the displacement since the strong ground motion observation network is denser than GNSS network in Japan.

The seismic acceleration record observed by a servo-seismometer is often contaminated by the baseline change due to the tilt motion of the apparatus, the effect of the electric hysteresis, and so on. For this reason, it is difficult to obtain the time series of the displacement including the residual component from the record. In such case, it is necessary to correct the baseline change of the accelerogram.

In this study, a new calculation technique is proposed to estimate the seismic displacement from the strong motion acceleration record. In the method, the time series of the displacement including the residual component is obtained by eliminating the step function component from the acceleration record in the frequency domain. The parameters of the step function component are determined to reduce the fluctuation of the displacement of coda part.

Applying the method to some acceleration records of the main shock of the 2016 Kumamoto Earthquake, the displacements are estimated more accurate than those estimated by existing method. In addition, the orbit of the particle motion can be drawn using the displacement estimated by the method. According to the result, it is revealed that the ground at Nishihara station went down about $150 \mathrm{~cm}$ and then consequently moved to east about $200 \mathrm{~cm}$. Furthermore, the distribution of the residual displacement of the main shock of the 2016 Kumamoto Earthquake estimated by proposed method almost agrees with that obtained by GNSS observation. 